\title{
THE PECULIARITIES OF SELF-REGULATION OF FUTURE MUSIC TEACHERS DURING THE PRACTICE
}

\author{
Rasa Kirliauskienè \\ Lithuanian University of Educational Sciences, Lithuania
}

\begin{abstract}
Each teacher compulsorily appears before class. He or she perceives all the emotional experiences characteristic of being in front of the audience. Not only the homeostasis disorder, which appears through physiological symptoms, bothers the students, they are also distracted by the variety of thoughts, which prevents them from focusing and disposing themselves to the performance. Thus, self-regulation is very important in future music teachers' training. The research has disclosed the factors promoting positive students' state during lesson, those are: preparation for the lesson, stage experience and experience in conducting lessons, musical skills and personal qualities, positive attitude and confidence. According to respondents, serious preparation improves one's state in a lesson, while learners feel more interested. The conducting of a lesson is associated with being on stage. Informants have mentioned that musical skills are very important when conducting a music lesson, since perfect singing, use of instruments etc., strengthens teacher's authority. In addition, positive attitude and confidence are necessary when willing to achieve harmony in class. Furthermore, personal qualities are an important subcategory according to students, when naming the reasons of appearance of stage fright. The evaluation and support are very important for especially sensitive people.
\end{abstract}

Keywords: future music teacher's training, stage fright, self-regulation, school practice

\section{Introduction}

Goleman (2015) states that emotions are influenced by biological impulses, which are much more far away from the borders of one's control, while caused emotions are not, thus, when emotions strongly influence the person, they cannot be ignored - they must be carefully managed. It is called self-regulation, the sign of emotional intellect, which frees from belonging to such stimuli. Koole, Van Dillen \& Sheppes (2011) agree to that idea by encouraging not fighting with fear in the mind, rather overcoming it by changing one's thoughts. It is difficult to control emotions, but it is possible to choose the way of reacting to them by means of self-control, awareness of one's moods, analysing them and behaving appropriately (Moestl, 2009). Whereas theoretical conceptions of cognitive development suggest that people's knowledge will vary depending on their individual developmental level and previous experiences, motivational theory strives to clarify the cognitive and affective processes that instigate, direct and sustain human action by studying how these processes operate as goals, expectations, attributions, values and emotions (Schunk \& Miller, 2002). McPherson \& McCormick (2006) state that selfefficacy theory deserves more focused attention by music researchers. This is especially important in a discipline that involves high levels of self-regulation and mental discipline, in the form of practising at home for long periods and for many years, in order to achieve success. During the research (Kirliauskiene, 2017), the following reasons for emergence of stage fright have been highlighted: lack of self-confidence and preparation, lack of stage experience and personal qualities. According to informants, more gifted colleagues, who have better skills and carry out different activities more successfully, influence lack of confidence, as well as, still present memories of a music school, while lack of preparation evokes the early anxiety and uncertainty. The lack of stage experience does not allow to relax and experience the happiness of performing on stage, but it is believed that by gradually gaining more and more musical and stage experience, the quality of performance and well-being on stage will also be improving. Evaluation and support are very important for especially sensitive 
people. It is not rare that practicing music alone is qualitative and helps to relax, but being on stage is more binding and often elicits various unexpected things, which become one more reason for the emergence of stage fright. Personality traits are defined as "relatively enduring patterns of thoughts, feelings, and behaviours that distinguish individuals from one another" (Roberts \& Mroczek, 2008, p. 31). Unlike conceptualizations of temperament, classic conceptualizations of personality typically do not include notions of reactivity and selfregulation. However, Denissen and colleagues (Denissen, Aken, Penke \& Wood, 2013) proposed a regulatory model of adult personality traits in which behaviours are interpreted as functional reactions to environmental features, that is, behaviours are meant to achieve certain desired future states. Kılıç (2017) investigated the relations among pre-service music teachers' musical instrument performance self-efficacy, music performance anxiety and self-esteem. Furthermore, researchers also have found that music students' practice effectiveness tends to be positively related to their self beliefs regarding their musical competence and degree of commitment to music studies (McPherson \& Zimmerman, 2011). The concept of self-regulation is one of the most difficult concepts and scientists investigate it in different aspects (Girgin, 2017; Zimmerman \& Schunk, 2008; Teixeira Dos Santos \& Capparelli Gerling, 2011; Leon-Guerrero, 2008; Van Eekelen, Boshuizen \& Vermunt, 2005; Ali, 2010; Nielsen, 2001; Panadero, Alonso-Tapia, Reche, 2013; Jale, 2012). These differences elicit the emotional tension during the practice, thus, the problem becomes even more relevant. Therefore, the aim of this research is to disclose the peculiarities of self-regulation of future music teachers during the practice.

\section{Methods of the research}

Methods of research and sample: analysis of scientific literature sources, interview. Qualitative research data are described applying content analysis. The scheme of categorisation was not planned in advance and it was devised on the basis of the received data. The research was carried out in 2016 -2017. The semi-structured (oral) interview was employed. Thirty-five future music teachers in their fourth year of studies from the Lithuanian University of Educational Sciences participated in this study. Participation in the study was voluntary. Informants were asked to express their opinion about the content of the role of a contemporary music teacher. The question about significance of personality was not presented to the informants making attempts to envisage the vision of the young generation (i.e., music teachers to be) about what a school teacher should be like and then the researcher searched for certain links to substantiate own theory.

The focus of the next stage of the research was on subjective opinion of the informants about some complex questions: In your opinion, what qualities should a contemporary music teacher have? What do you know about self-regulation? What methods of self-regulation do you know? What do you need to do to successfully perform in your lesson? The survey consisted of four complex questions, presented in research findings and their discussion.

\section{Results and discussion}

In the first research stage it was aimed to reveal the future music teachers' attitude to content of the role of a contemporary music teacher. The research data identified the content of the role of a music teacher pointing out its 5 aspects: educator (education for humanity: humanity, communication, playing music together); authority (competent specialist: example for school learners, profound knowledge of study subject, universality); importance of teacher's personality (aspects of teacher's personality: ability to arouse learners' interest, ability to be a friend, teacher's charismatic personality, flexibility); creativity (manifestations of creativity: teacher's creativity, ability to develop students' creativity, improvisation, revelation of students' personality through creative expression) and value-based aspects (enlightener of students' souls, nurturer of beauty of life, provision of sense to new impressions, expression of emotions).

Applying content analysis method informants' responses were divided into categories and subcategories. In Table 1 are provided statements which justify the importance of teacher's personality. 
Table 1 Students' attitude to content of the role of a contemporary music teacher: the importance of teacher's personality

\begin{tabular}{|c|c|c|}
\hline Category & Subcategory & Proving statements \\
\hline \multirow[t]{4}{*}{$\begin{array}{l}\text { Aspects of } \\
\text { teacher's } \\
\text { personality }\end{array}$} & $\begin{array}{l}\text { Ability to arouse } \\
\text { learner's interest }\end{array}$ & $\begin{array}{l}\text { "I think one of the main characteristics of a good } \\
\text { teacher is the ability to attract a child with his } \\
\text { personality }<\ldots \text {.. ". "It is important that the music } \\
\text { teacher presents his lessons interestingly and involves } \\
\text { pupils, then, they would not lose the motivation for } \\
\text { learning, their interest in music". "Music teacher, I } \\
\text { think, must be the one who, overall, in pupils' } \\
\text { education, activities, cannot be indifferent, must do } \\
\text { everything with confidently and especially } \\
\text { thoughtfully. He must strive for the pupils; leave the } \\
\text { footprint in the pupils' learning process". }\end{array}$ \\
\hline & Ability to be a friend & $\begin{array}{l}\text { "For the teacher it is also very relevant to be able to } \\
\text { be "a teacher-friend" and "teacher-guide" to maintain } \\
\text { friendly contact with the pupils, but also be an } \\
\text { authority". "Music teacher should not only be the } \\
\text { spreader of a qualitative music, but also a friend for } \\
\text { the pupils". }\end{array}$ \\
\hline & $\begin{array}{l}\text { Teacher's } \\
\text { charismatic } \\
\text { personality }\end{array}$ & $\begin{array}{l}\langle\ldots\rangle \text { it is essential that a good teacher would be } \\
\text { charismatic }<\ldots>\text { ".. "The teacher should have a } \\
\text { charismatic personality, be psychologically ready, } \\
\text { which could affect his learners and inspire them". } \\
\text { "Music teacher should be charismatic, "kindled" } \\
\text { teacher, who would not stop to improve himself". }\end{array}$ \\
\hline & Flexibility & $\begin{array}{l}\text { "It is important that the music teacher would be } \\
\text { flexible (would not stop at one or another method of } \\
\text { education)". "Always the situation should be assessed } \\
\text { adequately and decision making should be flexible". } \\
\text { "The situation should be assessed and decision } \\
\text { making should be flexible during the lesson". }\end{array}$ \\
\hline
\end{tabular}

In Table 1 are distinguished teacher's personality-related aspects. In subject's opinion, most important is to attract pupils, interest them: "it is important that the music teacher presents his lessons interestingly and would involve pupils, then, they would not lose the motivation for learning, their interest in music". Teacher needs to be able to be a friend, flexibly make decisions and be charismatic: "the teacher should have a charismatic personality, psychologically ready, which could affect his learners and inspire them". It is very important that the teacher would be an example for the pupils, and his words would not differ from the deeds, also are emphasized teacher's universality, contemporariness, which occurs from knowing not only his or her specific subject, but other subjects as well. During the research, it was relevant to find out the factors promoting positive students' state in the lesson (see Table 2).

Table 2 Factors promoting positive students'state during lessons: preparation and experience

\begin{tabular}{|c|c|c|}
\hline Category & Subcategory & Proving statements \\
\hline \multirow[t]{2}{*}{$\begin{array}{l}\text { Promoting } \\
\text { Factors }\end{array}$} & $\begin{array}{l}\text { Preparation } \\
\text { for the lesson }\end{array}$ & $\begin{array}{l}\text { "Preparation has a very big influence. The more } \\
\text { interesting you will make the lesson, the better you } \\
\text { will feel when children will be interested". "Good } \\
\text { preparation, considering various situations, foreseeing } \\
\text { unexpected issues, and learning to sing or play } \\
\text { perfectly the chosen music piece provide with } \\
\text { confidence and satisfaction in the lesson". }\end{array}$ \\
\hline & Stage experience & $"<\ldots>$ in school as on stage we stand in front of \\
\hline
\end{tabular}


children, speak in front of them, teach and all those are the same things as on stage $<\ldots$.. " " $<\ldots$.. I feel the same in front of the class too $<\ldots$.. ". "Stage experience particularly helps when in front of the class, since you convince yourself that you performed well in a big hall, thus, it would be shameful to get flustered in front of thirty children".

Experience "The more lessons you conduct, the better you feel, in both experiences merge". "I want to be a music

conducting lessons teacher, so each lesson is an interesting achievement for me, even though I can't defeat the anxiety <...>". "Of course, the more I perform the more experience I gain the better I feel during lesson; sometimes I'm able to relax $<\ldots>$ ".

The research has disclosed the factors promoting positive students' state during lesson (Table $2 \& 3$ ), those are: preparation for the lesson, stage experience and experience in conducting lessons, musical skills and personal qualities, positive attitude and confidence. According to respondents, serious preparation improves one's state in a lesson, while learners feel more interested. The conducting of a lesson is associated with being on stage: " $<\ldots>$ in school as on stage we stand in front of children, speak in front of them, teach and all those are the same things as on stage $<\ldots>$ ".

Table 3 Factors promoting positive students'state during lessons: musical skills, personal qualities, positive attitude, confidence

\begin{tabular}{|c|c|c|}
\hline Category & Subcategory & Proving statements \\
\hline \multirow[t]{4}{*}{$\begin{array}{l}\text { Promoting } \\
\text { Factors }\end{array}$} & Musical skills & $\begin{array}{l}\text { " }<\ldots>\text { musical skills are important, since only } \\
\text { theoretical knowledge". " }<\ldots>\text { are very important, of } \\
\text { course, }<\ldots>\text { the skills are necessary, it is still } \\
\text { required to play and know how to sing especially". "If } \\
\text { you can play some kind of instrument or grand piano } \\
\text { very well, then your lesson is successful and you feel } \\
\text { wonderful"." }<\ldots>\text { you can play or sing something to } \\
\text { the pupil, show your skills and he/she will think that } \\
\text { you are an authority". }\end{array}$ \\
\hline & Personal qualities & $\begin{array}{l}<\ldots>\text { is not enough to elicit interest and engage child } \\
\text { in educational process". " }<\ldots>\text { I think that one of the } \\
\text { most important qualities to feel well in the classroom } \\
\text { is creativity. Speaking skills and fast orientation are } \\
\text { also very important". "Sincerity, kindness, wish to } \\
\text { communicate are the personal qualities, which help to } \\
\text { maintain a positive state in a lesson". }\end{array}$ \\
\hline & Positive attitude & $\begin{array}{l}\text { "Without a positive attitude it is better not to go to } \\
\text { class, children react to that quite sensitively". }<\ldots> \\
\text { also, you need to ,put on" a positive attitude when } \\
\text { going to class". }\end{array}$ \\
\hline & Confidence & $\begin{array}{l}\text { "Confidence is important, if you don't trust yourself } \\
\text { children will notice that very fast and will stop } \\
\text { listening". "If a teacher is self-confident - he does } \\
\text { everything confidently <... ". "I think that } \\
\text { confidence is very important teacher's quality. When } \\
\text { you are confident you know what you are doing, } \\
\text { saying, how you behave, then learners trust such a } \\
\text { teacher". }\end{array}$ \\
\hline
\end{tabular}


Informants have mentioned (Table 3) that musical skills are very important when conducting a music lesson, since perfect singing, use of instruments etc., strengthens teacher's authority. Personal qualities according to the respondents: "Sincerity, kindness, wish to communicate $<\ldots>$ help to maintain a positive state in a lesson". Moreover, positive attitude and confidence are necessary when willing to achieve harmony in class. The analysis of the results showed that the vast majority of subjects indicate creativity as a necessary component in the music lesson and it helps to relax (see Table 4).

Table 4 Students' attitude to content of the role of a contemporary music teacher: creativity

\begin{tabular}{|c|c|c|}
\hline Category & Subcategory & Proving statements \\
\hline \multirow[t]{4}{*}{$\begin{array}{l}\text { Manifestation of } \\
\text { creativity }\end{array}$} & Teacher's creativity & $\begin{array}{l}\text { "The teacher should also be creative, so that he could } \\
\text { present the lessons in an interesting way, creatively } \\
\text { and pupils would easier remember the essential } \\
\text { things, so that it would not be boring and pupils } \\
\text { would not lose their motivation for learning, their } \\
\text { interest in music". "Music teacher should be creative, } \\
\text { original <...". "I understood by observing the } \\
\text { lessons of other teachers, that the "old" theoretical } \\
\text { knowledge did not interest pupils, to them, music } \\
\text { does not seem to be interesting, so I think that only a } \\
\text { creative teacher can change the situation". "Music } \\
\text { teacher - a generator of ideas". }\end{array}$ \\
\hline & $\begin{array}{l}\text { Ability to develop } \\
\text { students' creativity }\end{array}$ & $\begin{array}{l}\text { "Another one of the important music teacher's } \\
\text { abilities is to be continually cultivating pupils" } \\
\text { creativity }<\ldots \text { ".." "Music teacher -motivator of } \\
\text { creativity". "The teacher should encourage children's } \\
\text { creativity by creating favourable for them } \\
\text { conditions". "Allow children's creativity to express } \\
\text { itself during music lessons". }\end{array}$ \\
\hline & Improvisation & $\begin{array}{l}\text { "Music lesson can be turned into creative work, } \\
\text { improvisation's lesson". "During the lesson it can be } \\
\text { deviated from the theoretical material, adding creative } \\
\text { work, improvisation, concert viewing (video, clip) } \\
\text { and later come back to certain things". "In my music } \\
\text { lesson I would use more creative, improvisation } \\
\text { methods. I would be able to interest children so that } \\
\text { they would not want to leave my music lesson". }\end{array}$ \\
\hline & $\begin{array}{c}\text { Revelation of students } \\
\text { personality through } \\
\text { creative expression }\end{array}$ & $\begin{array}{l}\text { "The teacher should be able to come up with such } \\
\text { activities, through which pupils could express } \\
\text { themselves, disclose and develop various human } \\
\text { values". "<...> let them unfold, get involved in the } \\
\text { taught subject and interest them". "The teacher has to } \\
\text { raise the interest of students, otherwise, the lesson - } \\
\text { failure. To interest means to do so that the child could } \\
\text { join the lesson, not only to participate in it, but also } \\
\text { could reveal himself". }\end{array}$ \\
\hline
\end{tabular}

While analysing the statements (Table 4) related to the creativity's expressions, were distinguished subcategories: teacher's creativity, the ability to develop student's creativity, improvisation and revelation of student's personality through creative expression. It is relevant that the teacher would be creative, would not only follow the textbook, would generate new ideas: "music teacher should be creative, original $\langle\ldots\rangle$; " $<\ldots>$ the "old" theoretical knowledge did not interest pupils, to them, music does not seem to be interesting, so I think that only a creative teacher can change the situation". Respondents noted that it is very important that the music teacher would be able to encourage children's creativity: "music teacher - motivator of creativity" and would be able to reveal the student's personality through creative expression: "the teacher should be able to 
come up with such activities, through which pupils could express themselves, disclose and develop various human values". Also, the subjects have distinguished the importance of improvisation: "in my music lesson I would use more creative, improvisation methods. I would be able to interest children so that they would not want to leave my music lesson".

In the next research stage was discovered that the stage fright manifests itself in physiological, mental and behavioural symptoms. Respondents state that they are bothered by dry mouth, trembling voice and breathing disorders while singing or speaking (when presenting a report, conducting a lesson). They also feel the faster heart beat during various activities.

Having determined the symptoms of stage fright, it was also relevant to find out what the respondents know about the concept of self-regulation (see Table 5).

Table 5 Concept of self-regulation according to students

\begin{tabular}{|c|c|c|}
\hline Category & Subcategory & Proving statements \\
\hline \multirow[t]{3}{*}{$\begin{array}{l}\text { Concept of self- } \\
\text { regulation }\end{array}$} & Ability to relax & $\begin{array}{l}\text { "It is like an ability to relax". "If it is an extreme } \\
\text { situation and you can calm yourself down and relax } \\
<\ldots . \text { ". "Self-regulation enables you to be confident, } \\
\text { helps to not fear and worry <..." "Self-regulation - } \\
\text { necessary condition while performing musical } \\
\text { activities, like ability to relax". "If there is no self- } \\
\text { regulation which is a necessary condition of } \\
\text { performing any activity, then, the quality suffers, } \\
\text { sometimes it is unexpected, a lot of mistakes appear, } \\
\text { etc.". }\end{array}$ \\
\hline & Positive attitude & $\begin{array}{l}\text { "I always try to indispose myself positively, that } \\
\text { everything will succeed and go well, I think that it } \\
\text { helps more than fear, which can conquer thoughts and } \\
\text { not only them, hands and legs can start shaking and } \\
\text { etc.". "<...> indisposing oneself positively for a } \\
\text { concert has a lot of influence, that is, in my opinion, } \\
\text { self-regulation }<\ldots \text {..." "Positive attitude, calm } \\
\text { environment and support of friends help me relax, this } \\
\text { way self-regulation is expressed". }\end{array}$ \\
\hline & Mind control & $\begin{array}{l}\text { "You become overwhelmed by the abundance of } \\
\text { thoughts cannot control them, but if self-regulation } \\
\text { works, you are able to turn your thoughts towards } \\
\text { positive direction }<\ldots . \text { ". "<...> if anxiety will } \\
\text { strangulate, you will not be able to do anything, } \\
\text { which means thoughts need to be controlled, so that } \\
\text { this does not happen". "Of course, self-regulation is } \\
\text { important - mind control towards the direction } \\
\text { appropriate for the situation: would that be playing an } \\
\text { instrument, singing or laying out the ideas in the } \\
\text { classroom }<\ldots \text {..." }\end{array}$ \\
\hline
\end{tabular}

The subcategories of the concept of self-regulation are highlighted in Table 5: ability to relax, positive attitude and mind control. Informants realise the significance of the concept of self-regulation in the activities of future music teachers. They state that self- regulation is necessary while performing teacher's activities: conducting lessons, singing, playing, conducting, etc. According to students, the essence of self-regulation lies in the ability to relax, have a positive attitude and controlling one's mind: "you become overwhelmed by the abundance of thoughts, cannot control them, but if self-regulation works, you are able to turn your thoughts towards positive direction $<\ldots>$ '. Furthermore, if there is no self-regulation or it is forgotten, then suffers the quality of activity: 
"if there is no self-regulation which is a necessary condition of performing any activity, then, the quality suffers, sometimes it is unexpected, a lot of mistakes appear, etc.".

During the other stage of research, it was analysed what ways of self-regulation are known to future music teachers (see Table 6).

Table 6 Ways of self-regulation according to students

\begin{tabular}{|c|c|c|}
\hline Category & Subcategory & Proving statements \\
\hline \multirow[t]{4}{*}{$\begin{array}{l}\text { Ways of self- } \\
\text { regulation }\end{array}$} & Breathing exercise & $\begin{array}{l}\text { "Breathing exercises help a lot before going on } \\
\text { stage". " }<\ldots>\text { I have long been using various relaxing } \\
\text { exercises; they help me to relax }<\ldots>\text {. "Breathing } \\
\text { exercises not only help to relax, but also direct } \\
\text { thoughts away from anxiety; I just concentrate at that } \\
\text { time on breathing }\end{array}$ \\
\hline & $\begin{array}{l}\text { Positive self- } \\
\text { suggestion }\end{array}$ & $\begin{array}{l}\text { "Most often negative thoughts overwhelm, but I know } \\
\text { what follow, so I always make myself think } \\
\text { positively". "I am helped by the positive thoughts that } \\
\text { everything will be fine, I will succeed in playing, } \\
\text { since I have learned it perfectly <...>". } \\
\text { "Psychological attitude is the most important - that } \\
\text { everything will be fine, just indispose yourself so. } \\
\text { And it really helps }<\ldots \text {..". }\end{array}$ \\
\hline & $\begin{array}{l}\text { Being alone and } \\
\text { focusing }\end{array}$ & $\begin{array}{l}\text { "I like to stay alone and focus }<\ldots>\text { ". "I step aside, do } \\
\text { not participate in any talk, focus and attempt to repeat } \\
\text { the most difficult parts in my mind. It makes me } \\
\text { happy if I can recreate them without the instrument, } \\
\text { sometimes happens that I start worrying if I fail to } \\
\text { remember without the instrument, then I run into the } \\
\text { free room to revise the forgotten part". "I advise to } \\
\text { concentrate the most on that future activity, for } \\
\text { example, even if you know that you need to } \\
\text { accompany, play or conduct, automatically do not } \\
\text { see, hear anything, just focus on what awaits you and } \\
\text { it will help, since there will be only you and your } \\
\text { activity". }\end{array}$ \\
\hline & $\begin{array}{c}\text { Encouraging self- } \\
\text { confidence }\end{array}$ & $\begin{array}{l}\text { "I often repeat: I can, I will succeed, I am confident } \\
<\ldots \text {...". "If I only start feeling that fear is rising, I start } \\
\text { to repeat to myself the words of self-confidence, I } \\
\text { think, confidence helps more than doubts, they only } \\
\text { destroy the performance". "The encouragement of } \\
\text { self-confidence is very important; teachers also } \\
\text { should encourage students to trust themselves more } \\
<\ldots . .>\text {. }\end{array}$ \\
\hline
\end{tabular}

Ways of self-regulation (Table 6) according to respondents are based on breathing exercises, positive selfsuggestion, being alone and focusing and encouraging self-confidence. Breathing exercises not only help to relax, but also direct the thoughts away from negative feelings, while concentrating on the performance of exercises and focusing on that activity. Informants think that positive mind control is one of the ways of selfregulation enabling to help oneself before the performance, when negative thoughts about the future performance overwhelm: "Psychological attitude is the most important - that everything will be fine, just indispose yourself so. And it really helps $<\ldots>$ ”. Very often before the performance gathered students can be observed, who try to distract themselves and their friends by describing funny adventures, various stories, willing this way to distract their attention from performance. However, respondents state the way opposite to that one, mentioning as one of the possible self-regulation ways staying alone and focusing: "I like to stay alone 
and focus $<\ldots>$ ". The respondents also assign the encouragement of self-confidence to the ways of selfregulation. They think that lack of confidence may damage the quality of performance, thus, it is necessary to encourage self-confidence, which should be also done by teachers, constantly encouraging learners' selfconfidence.

Research results presented in Table 7 reflect the students' well-being during certain activities. The category of students' well-being, is divided into subcategories: public performance (concert), performance during exams and conducting a lesson. Informants state that during concerts they experience strong anxiety, which is associated with responsibility that they feel while performing in front of a big audience.

Table 7 Analysis of students' well-being

\begin{tabular}{|c|c|c|}
\hline Category & Subcategory & Proving statements \\
\hline \multirow[t]{3}{*}{$\begin{array}{l}\text { Students' well- } \\
\text { being }\end{array}$} & $\begin{array}{l}\text { Public performance } \\
\text { (concert) }\end{array}$ & $\begin{array}{l}\text { "If I know that I will have to perform in front of a big } \\
\text { audience, anxiety intensifies }<\ldots \text {...". "Responsibility is } \\
\text { very important, you cannot let down the people who } \\
\text { trust you; one thing is to play alone and completely } \\
\text { different when many people are listening to you, since } \\
\text { you cannot start again from the beginning if you fail". } \\
\text { "I like to play or sing to the audience in which there is } \\
\text { no familiar people the most, since I don't want to hear } \\
\text { criticism because things do not always succeed } \\
<\ldots . \text { ". }\end{array}$ \\
\hline & $\begin{array}{l}\text { Performance during } \\
\text { exams }\end{array}$ & $\begin{array}{l}\text { "The evaluation is very important for me, so I'm } \\
\text { always very nervous during exams; I don't think that } \\
\text { it can be any other way }<. . . \text { ". "It is linked to } \\
\text { evaluation, if there wouldn't be a grade, I could relax } \\
\text { more and my performance would be more musical } \\
<\ldots . \text { ". "I try to perform as good as possible, but not } \\
\text { always succeed, maybe I lack confidence, and } \\
\text { sometimes maybe I don't like the program which I } \\
\text { perform }<\ldots>\text { ". }\end{array}$ \\
\hline & Conducting a lesson & $\begin{array}{l}\text { "My first lessons weren't very successful because I } \\
\text { felt a strong anxiety, now I already feel more } \\
\text { confident, thus, I feel better too }<\ldots \text {.. >". "I want to be } \\
\text { a music teacher, so each lesson is an interesting } \\
\text { achievement for me, even though I can't defeat the } \\
\text { anxiety }<\ldots \text {...". "I don't think that I have sufficient } \\
\text { skills for all the activities, but I feel good enough } \\
\text { when conducting, thus, I conduct a lot when teaching } \\
\text { solfeggio, songs and even for rhythmic exercises". }\end{array}$ \\
\hline
\end{tabular}

Students are afraid of criticism, thus, they prefer to perform to unfamiliar audience (see Table 7). Strong nervousness is typical during exams as well, since it is linked to evaluation. The presumption is that performance could be qualitative and musical if there would be no evaluation grades. Moreover, it is mentioned that sometimes there is a lack of self-confidence and sometimes the choice of program influences the quality of performance. While evaluating their well-being during conducting lessons, respondents have noticed that first lessons were not successful, since the strong anxiety was felt, but by conducting more and more lessons selfconfidence and well-being are improved. It is also achieved with the help of strengthened motivation to become a music teacher and the choice of activities: "I don't think that I have sufficient skills for all the activities, but I feel good enough when conducting, thus, I conduct a lot when teaching solfeggio, songs and even for rhythmic exercises". 
In summary, it can be said that self-regulation is a necessary component when optimizing the scenic state. It is impossible to avoid negative thoughts, but it is also very important to substitute them with positive ones (positive attitude), while conscious psychological guidance for physical and psychological body stands - factor of successful performance.

\section{Conclusions}

The research has disclosed the factors promoting positive students' state during lesson: preparation for the lesson, stage experience and experience in conducting lessons, musical skills and personal qualities, positive attitude and confidence. According to respondents, serious preparation improves one's state in a lesson, while learners feel more interested. The conducting of a lesson is associated with being on stage. Informants have mentioned that musical skills are very important when conducting a music lesson, since perfect singing, use of instruments etc., strengthens teacher's authority. In addition, positive attitude and confidence are necessary when willing to achieve harmony in class. The results have also disclosed creativity as a factor which helps to relax much more in different activities in the class.

While evaluating their well-being during conducting lessons, respondents have noticed that first lessons were not successful, since the strong anxiety was felt, but by conducting more and more lessons self-confidence and well-being are improved. It could also be achieved with the help of motivation to become a music teacher and choice of appropriate activities.

Factors disclosed in the process of research that promote the positive students' state while on stage are the following: assuredness, level of preparedness, musical skills, stage experience, personal qualities, favourable environment and support. According to informants, appropriate preparation strengthens not only positive stage well-being, but also confidence; however, when going on stage adequate evaluation of one's abilities is required. They mostly like to perform in the environment, where they feel support, being needed and safety. Informants agree that when going on stage are required decisiveness, good musical skills and a wish to share artistic performance, while positive state is promoted by the strive for attention and glory.

According to informants, the concept of self-regulation is disclosed through ability to relax, positive attitude and mind control. Self-regulation is necessary while performing the teacher's activities: conducting lessons, singing, playing, conducting, etc. Ways of self-regulation according to respondents are based on breathing exercises, positive self-suggestion, being alone and focusing and encouraging self-confidence.

\section{References}

Ali, S., 2010, Understanding Our Students' Self-Regulation During Practice: Verbal Protocol as a Tool. Journal of singing, 66(5), 529-536.

Denissen, J. J. A., van Aken, M. A. G., Penke, L., Wood, D, 2013, Self-Regulation Underlies Temperament and Personality: An Integrative Developmental Framework. Child Development Perspectives, 7(4), 255-260.

Girgin, D., 2017, The relations among musical instrument performance self-efficacy, self-esteem and music performance anxiety in pre-service music teachers. Educational Research and Reviews, 12(11), 611-616.

Goleman, D., 2015, Self-Regulation: A Star Leader's Secret Weapon. Date of access: 03/01/2017, http://www.danielgoleman.info/daniel-goleman-self-regulation-a-star-leaders-secret-weapon/.

Jale, D., 2012, Video Recorded Feedback for Self Regulation of Prospective Music Teachers in Piano Lessons. Journal of Instructional Psychology, 39(1), 17-25.

Kılıç ÇDB, 2017, Pre-service music teachers' opinions about the teaching practicum course. Mariateresa Gammone/Mehmet Ali Icbay/Hasan Arslan (Ed.) Recent Developments in Education. International Association of Social Science Research, pp. 371-376.

Kirliauskienė, R., 2017, Self-regulation peculiarities of future music teachers. Educational Alternatives, 15, 100107. 
Koole, S. L., Van Dillen, L. F. and Sheppes, G., 2011, The self-regulation of emotion in Handbook of Selfregulation, eds. K. Vohs and R. Baumeister (New York, NY: Guilford Press), pp. 22-40.

Leon-Guerrero, A., 2008, Self-regulation strategies used by student musicians during music practice. Music Education Research, 10 (1), 91-106.

McPherson, G. E., and McCormick, J., 2006, Self-efficacy and music performance. Psychology of Music, 34(3), 322-336.

McPherson, G. E., Zimmerman, B. J., 2011, Self-regulation of musical learning: A social cognitive perspective on developing performance skills. In R. Colwell, P. Webster (Eds.), MENC Handbook of Research on Music Learning, Vol. 2 (New York, NY: Oxford University Press), pp. 130-175.

Moestl, B., 2009, Menas prisijaukinti drakona (Vilnius: Algarvė).

Nielsen, S., 2001, Self-regulating Learning Strategies in Instrumental Music Practice. Music Education Research, 3(2), 155-167.

Panadero, E., Alonso-Tapia, J., Reche E., 2013, Rubrics vs. self-assessment scripts effect on self-regulation, performance and self-efficacy in pre-service teachers. Studies in Educational Evaluation, 39, 125-132.

Roberts, B. W., Mroczek, D., 2008, Personality trait change in adulthood. Current Directions in Psychological Science, 17(1), 31-35.

Schunk, D. H. and Miller, S. D., 2002, Self-efficacy and Adolescents' Motivation, in F. Pajares and T. Urdan (eds.) Academic Motivation of Adolescents (Greenwich, CT: Information Age Publishing), pp.29-52.

Teixeira Dos Santos, R. A. \& Capparelli Gerling, C., 2011, (Dis)Similarities in music performance among selfregulated learners: an exploratory study. Music Education Research, 13(4), 431-446.

Van Eekelen, I. M., Boshuizen, H. P. A. \& Vermunt, J. D., 2005, Self-regulation in higher education teacher learning. Higher Education, 50, 447-471.

Zimmerman, B. J., \& Schunk, D. H., 2008, Motivation: An essential dimension of self-regulated learning. In

D. H. Schunk \& B. J. Zimmerman (Eds.): Motivation and self-regulated learning: Theory, research, and

applications (Boca Raton, FL: Erlbaum/Taylor \& Francis Group), pp. 1-30. 